\title{
MAYOR'S PUNS ON INSTAGRAM: CLASSIFICATION AND FUNCTION OF PUNS IN RIDWAN KAMIL'S INSTAGRAM ACCOUNT
}

\author{
Shafa Firda Nila \\ Universitas Bina Bangsa \\ shafa.firda@binabangsa.ac.id
}

\begin{abstract}
Many government officials use Instagram as a means of communication. In Indonesia, one of them is Ridwan Kamil, the mayor of Bandung City who has more than 7 million of followers on Instagram and has shared more than 4000 posts. A lot of his posts contain such hilarious wordplay, for example is puns. This research aims to identify the classification and function of puns found in Instagram posts of Ridwan Kamil. This study is qualitative descriptive research which describes a language phenomenon in social media. The researcher selected Instagram posts from an account @ridwankamil which contain puns as the samples. The period of the posts were taken during the year of 2017. The results show that there are five types of puns: homonymic pun, homophonic pun, paronymy, compund pun, and recursive pun. The puns have functions to create humor and to provide brevity and persuasion.
\end{abstract}

Keywords: puns, classification, function, Instagram

\section{INTRODUCTION}

Today, social media refers to a wide range of web sites and internet-based services that allow users to create content and interact with other users (Farzindar and Inkpen, 2017). Online discourse is often characterized as playful, humorous, and creative (Vasquez and Creel, 2017). The growing prevalence of digital communication in recent years has sparked scholarly interest in new media discourse across a range of disciplines, including communication studies, cognitive science, linguistics, and sociology (Lazaraton, 2014). Online social media are particularly promising resource for the study of people, as "status" updates are self-descriptive, personal, and have emotional content (Kramer in Schwartz et.al, 2013). Therefore, language use is objective and quantifiable behavioral data (Ireland and Mehl in Schwartz et.al, 2013)

Instagram is a mobile, desktop, and Internet-based photo-sharing application and service that allows users to share pictures and videos either publicly or privately to preapproved followers. Wikipedia wrote that after its launch in 2010, Instagram rapidly gained popularity, with one million registered users in two months, 10 million in a year, and ultimately 800 million as of September 2017. Its users have uploaded over 40 billion photos to the service as of October 2015. As of April 2017, Instagram Direct has 375 million active users, while, as of June 2017, the Instagram Stories functionality has over 250 million active users. Therefore, Instagram has been named "one of the most influential social networks in the world" (https://en.wikipedia.org/wiki/Instagram).

Famous celebrities, public figures, and ordinary people use Instagram to interact with their fans, citizens, families, and so many people in the world. Registered Instagram users can upload photos and videos, apply various digital filters to their images, add locations through geotags, and add hashtags to their posts, linking the photos up to other content on Instagram featuring the same subject or overall topic, connect their Instagram account to other social media profiles, enabling them to share photos to those profiles as well. Instagram also has a feature called Instagram Direct which allows users lets users interact through private messaging.

Many famous people such as celebrities or public figures have Instagram account followed by many people. In 2017, it was announced that Selena Gomez named as the most followed public figure on Instagram. Her Instagram account has 132 millions of followers. Moreover, many government officials also use Instagram as a means of communication. In Indonesia itself, one of them is Ridwan Kamil, the mayor of Bandung City who has more than 7 million of followers on Instagram and has shared more than 4000 posts. From his Instagram post on 1 January 2018, it was revealed that @ ridwankamil got 146 million of likes from the followers to 997 posts in 2017. Most of his posts are related to the information about Bandung, programs, events, achievements, his daily activities, and sometimes Regram (repost for Instagram) from his followers. What makes his posts are interesting is that Kang Emil-his famous nickname-often plays on words on his Instagram posts. A lot of his posts contain such hilarious wordplay, especially puns. He is often dubbed as "Walikota Zaman Now" for his anti-mainstream style. As the leader of Bandung, in which he described himself on his Instagram account as the caretaker of lovely Bandung, he is very different from what the so-called old fashioned government officials. The netizens like his funny-easy-going personality and would enthusiast to follow his Instagram account. Many of his 
followers are also people from outside Bandung and West Java.

\section{Punning to Play-On-Words}

As a form of language creativity, puns have been "the only legitimate field for the interdisciplinary contacts between linguistics and humor studies for a long time" (Attardo in Jojic, 2013). The main reason lies in the fact that, when compared with other forms of verbal humor, puns depend, to the utmost degree, on the way verbal expression is maneuvered (Ermida in Jojic, 2013). Of all the various forms of humor, plays on words and puns have received the bulk of attention in linguistic studies (Partington, 2009). Delabastita (in Diaz-Perez, 2012) defined wordplay as the general name indicating the various textual phenomena (i.e. on the level of performance or parole) in which certain features inherent in the structure of the language used (level of competence or langue) are exploited in such a way as to establish a communicatively significant, (near-) simultaneous confrontation of at least two linguistic structures with more or less dissimilar meanings (signified) and more or less similar forms (signifiers). Giorgadze (2014) explained that according to its form, wordplay can be expressed in ambiguous verbal wit, orthographic peculiarities, sounds and forms of the words, in breaking the grammar rules and other linguistic factors. It should be also mentioned that context has a vital importance for the actualization of the wordplay (pun), as its pragmatic role (mainly humorous, satirical, sarcastic, etc.) is fulfilled and actualized in a specific context. Therefore, wordplay and its categories are changeable expressive means and together with the development of languages, new types are formed and developed. (Giorgadze, 2014).

For better understanding, Giorgadze (2014) considered pun as one of the types of wordplay, whereas wordplay is classed as an umbrella term denoting all the subclasses, such as spoonerism, malapropism, wellerism, onomatopoeia, palindrome and other linguistic units. Quintilian (in van Mulken et.al, 2004) distinguished between puns in which both meanings are relevant and those for which only one meaning is relevant. Puns can provide pleasurable experience in several related ways. First, a pun is a humorous device. A humorous message can give the audience a pleasant experience. Second, a pun can be considered as a riddle. Solving a riddle is a pleasant experience, too, because it flatters the audience's intellectual capabilities by showing them that they have the relevant knowledge to solve the problem (van Mulken et.al, 2004). Puns are also intimately bound up with the culture of a language, reflecting particular values, tastes and lifestyles (Laviosa, 2005).

\section{Classification and Function of Pun}

Some scholars have classified pun into several categories. The classifications of pun by Delabastita and Gottlieb presented here were cited by Giorgadze (2014). According to Delabastita pun is divided into four categories:

1) Homonymy (identical sounds and spelling)

2) Homophony (identical sounds but different spellings)
3) Homography (different sounds but identical spelling)

4) Paronymy (there are slight differences in both spelling and sound)

Gottlieb's classification of pun is similar to Delabastita's one in which he only added and singled out three subcategories of homonymy:

1) Lexical homonymy (the central feature is single-word ambiguity)

2) Collocational homonymy (the word-in-context ambiguity is the central feature)

3) Phrasal homonymy (the clause ambiguity is the central feature)

Another classification of pun by Chuandao (2005) is different from the former two scholars'. Chuandao claimed that the creation of pun is connected not only to the meaning and the homophony of a word, but also to the context, manner of speech and logic. Therefore, he classified pun as follows:

1) Homonymic pun (identical sounds and spelling): the homonymic pun is the use of sound, and a way of utterance to use words unrelated in meaning but sounding alike to form two meanings ---- to use the homonymous relations between words to make an utterance have two different interpretations.

2) Lexical meaning pun (poly semantic words): the lexical meaning pun is an expressive way of utterance to use the polysemy of words to cause a sentence to have two different interpretations, and it is also a rhetorical device in which a certain feeling is transmitted.

3) Understanding pun (through the particular context implied meaning of a sentence is revealed): sometimes a pun sentence does not include any pun word. Instead it, through a particular context and with the help of it, can suggest the implied meaning of the sentence. This is called the understanding pun.

4) Figurative pun (a simile or a metaphor as its surface meaning and the figurative meaning as its deep meaning): this figure of speech is used directly in a sentence or in a context.

5) Logic pun (a rhetorical device, a kind of implication in a particular context): this pun is a kind of implication in a particular context. The listener may not feel it, but the reader can understand it. In a dialogue no word contains two meanings, but different roles in the dialogue obviously refer to various things in using the words. As a result double implication forms in the listener's mind. Then this forms a logic pun.

To complete the classification, Bader (2014) added some other types of pun in which he summarized from different authors:

1) Compound pun: it includes a statement that contains two or more puns. Example is Richard Whately's complex statement "Why can't a man starve in the GreatDesert? Because he can eat the sand which is there, but what brought sandwiches there? Noah sent 
Ham and his descendants mustered and bred." The pun here is first in the phrase sand which is, which is homophonic with sandwiches, and, second, in the homonymic words Ham (Noah's son) and ham (kind of pig meat), mustered/mustard, and bred/bread.

2) Recursive pun: the second aspect of the pun relies on the understanding of an element in the first aspect. Example is the statement "Infinity is not in finity", which means that infinity is not in the finite range. Another example is in Oscar Wilde - Immanuel doesn't pun, he Kant.

3) Visual pun: the pun aspects are replaced by a picture and this kind is sometimes used in cartoons like "The Far side".

As a special language device, puns enhance the appeal of a language and strengthen its informative effect and make language become more concise, funny, humorous, novel, and so on, and it will leave a deep impression on readers with readability and humor (Gan, 2015). Moreover, Gan (2015) explained that puns have different functions such as providing brevity, humor, satire, persuasion, and forming riddles.

\section{RESEARCH METHODS}

This study is qualitative descriptive research which describes a language phenomenon in social media. In qualitative research, the inquirer analyzes words or images (Creswell, 2012). This study used qualitative approach because the data is in the form of puns found in Instagram posts of Ridwan Kamil, the mayor of Bandung City. This study is also an embedded-case study because the problem and the focus of the research have been decided by the researcher. Case study is a design of inquiry found in many fields, especially evaluation, in which the researcher develops an in-depth analysis of a case, often a program, event, activity, process, or one or more individuals (Creswell, 2014). Cases are bounded by time and activity, and researchers collect detailed information using a variety of data collection procedures over a sustained period of time (Stake; Yin, as cited in Creswell, 2014).

Creswell (2012) stated that there are five interrelated steps in the process of qualitative data collection. The first is to identify participant and sites to be studied and to engage in sampling strategy. Second, is to gain access to these individuals and sites. Third, is to consider types of information that will best for research questions. Fourth, is to design protocols or instruments for collecting and recording the information. Finally, the fifth is to administer the data collection with special attention to potential ethical issues that may arise. However, these steps should not be seen as linear approaches, but often one step in the process does follow another (Creswell, 2012).

In qualitative inquiry, the intent is not to generalize to a population, but to develop an in-depth exploration of a central phenomenon. Thus, the qualitative researcher purposefully or intentionally selects individuals and sites. Therefore, the research term used for qualitative sampling is purposeful sampling. In this research, the researcher selected Instagram posts from an account @ ridwankamil which contain puns. The period of the posts is during the year of 2017 .

\section{FINDINGS AND DISCUSSION}

In this part, the researcher presents the result of the analysis and the discussion. The first part is the classification or types of pun found in Ridwan Kamil's posts on his Instagram account and the second part is the function of the puns.

\section{Classification or Types of Pun in Ridwan Kamil's Instagram Account}

\section{Homonymic Pun}

This is kind of pun with identical sounds and spelling. Some examples of homonymic pun in Ridwan Kamil's Instagram account are as follows:

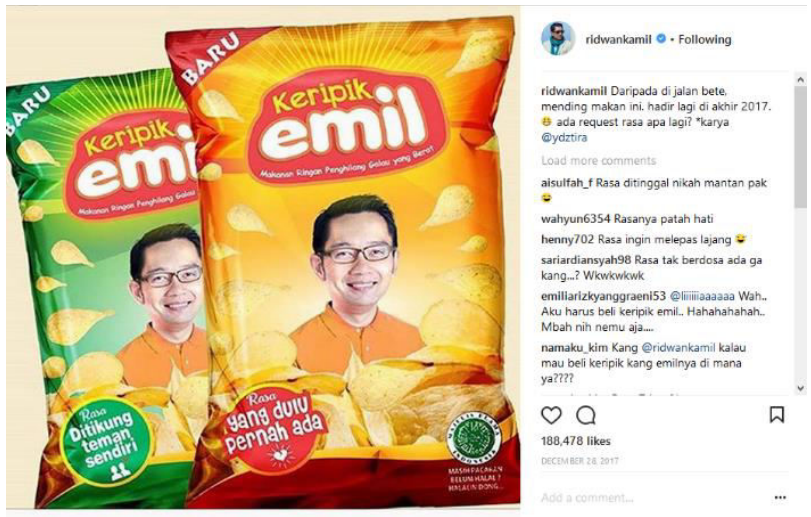

Picture 1

The homonymic puns on Picture 1 are rasa ditikung teman sendiri and rasa yang dulu pernah ada. The picture of snacks plays on pun of the word rasa. In terms of food, rasa is associated with taste whereas on the above example, rasa is associated with feeling. Another example:

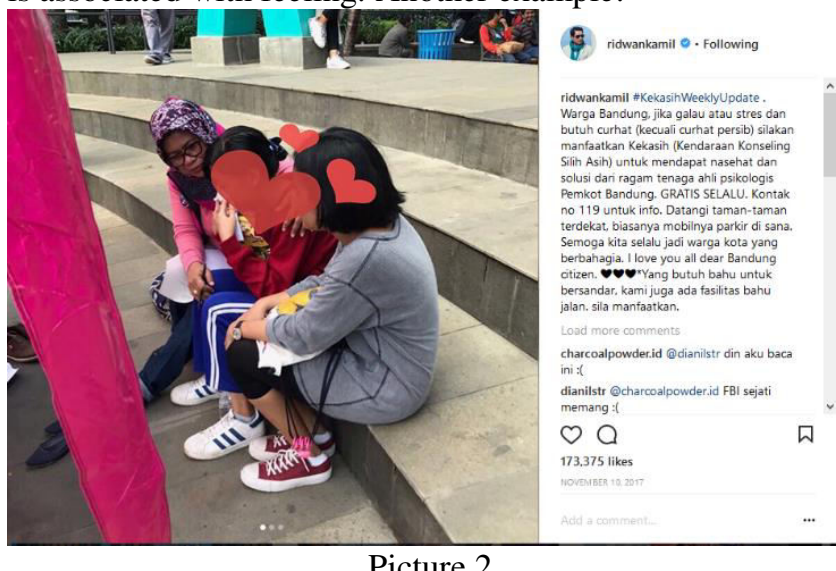

Picture 2

The Homonymic pun on Picture 2 is on the caption yang butuh bahu untuk bersandar, kami juga ada fasilitas bahu jalan. It is a common joke among Indonesian people. The word bahu (shoulder) can mean the part of body where arm is connected and also the part of a roadway outside of the traveled way.

\section{Homophonic Pun}


This pun relies on words that sound alike or similar sounds rather than a single word with multiple meanings. Some examples of homophonic pun in Ridwan Kamil's Instagram account are as follows:

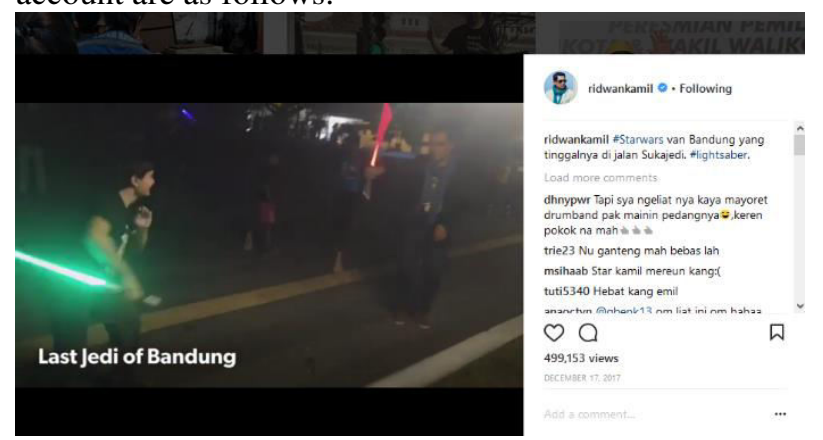

Picture 3

On the above example, the homophonic pun is Starwars van Bandung yang tinggalnya di jalan Sukajedi. Sukajedi here is a pun of Sukajadi. There is a homophonic relation between Sukajedi and Sukajadi. Sukajadi is name of a district in Bandung while Sukajedi is a pun derived from Jedi which is the main protagonist in the Star Wars movie. The context of the pun is explained by the picture in which Ridwan Kamil is playing a parody to act as a Jedi in one of the Star Wars movies The Last Jedi. Another example of homophonic pun:

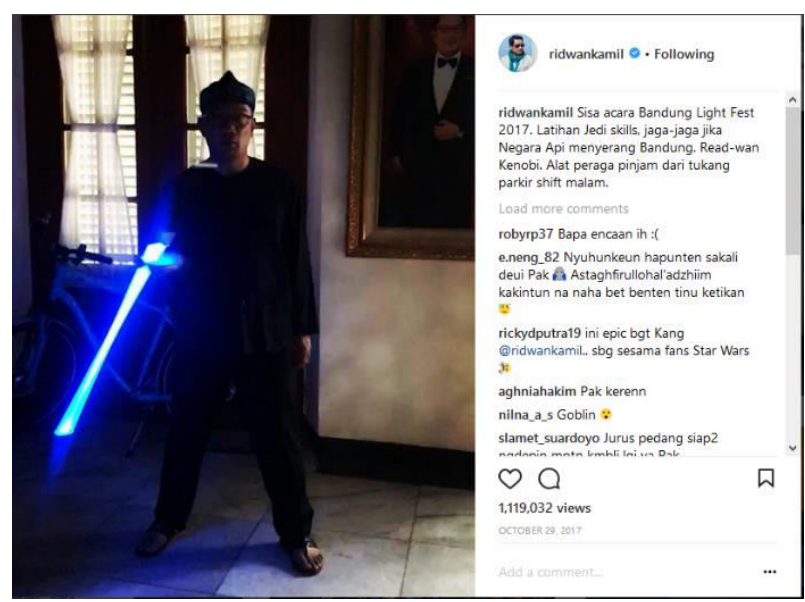

Picture 4

The homophonic pun is in the word Read-wan Kenobi. Read-wan has similar sound to his name Ridwan. The context of the pun is also a parody of Star Wars movie which is one of the characters named Obi-wan Kenobi. Another example:

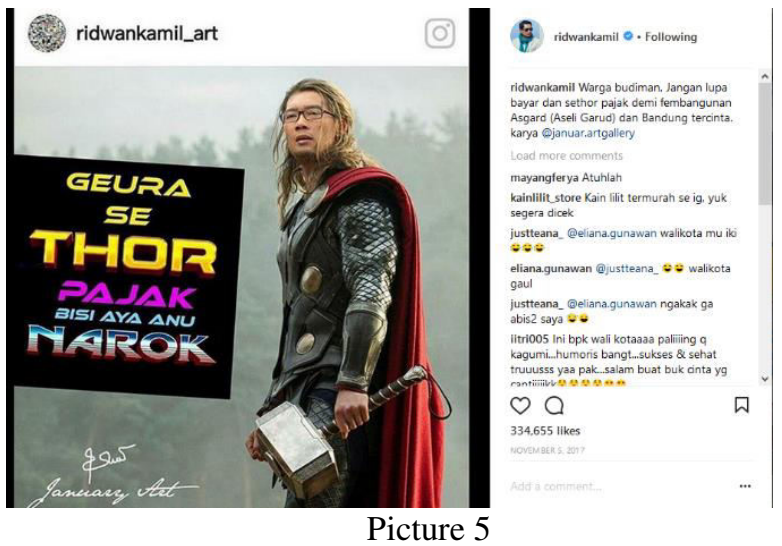

The homophonic pun is in geura seThor pajak bisi aya anu narok. SeThor is pun of setor (to pay money or something). The pun is visualized in which Ridwan Kamil depicted as one of the character of Marvel's superhero, Thor.

\section{Paronymy}

This is kind of pun which has slight differences in both spelling and sound. The formation of a word is based on a word from another language with little or no alteration in spelling or pronunciation. Some examples of paronymy in Ridwan Kamil's Instagram account are as follows:

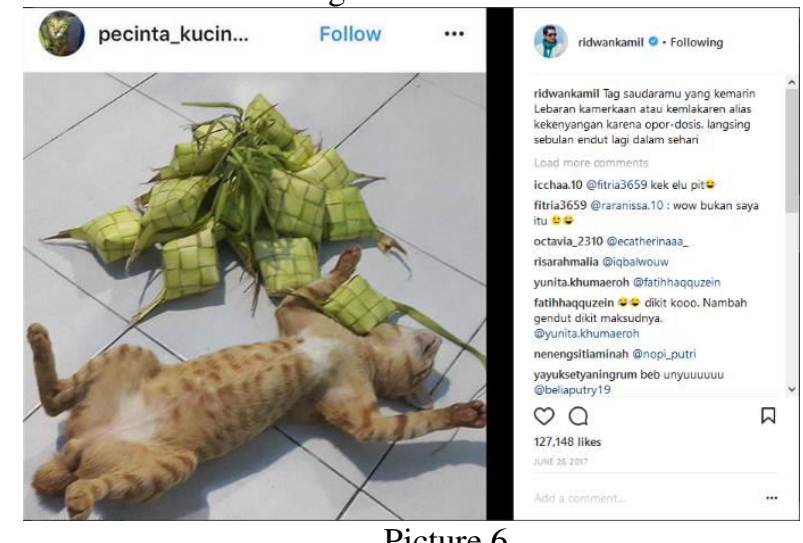

The paronymy occurred in the word opor-dosis which is the pun of over-dosis (overdose). The context of the pun described the typical cuisine of Eid al-Fitri in Indonesia. People in Indonesia usually serve ketupat (rice cake) and opor ayam (typical of Indonesian chicken curry) as the menu. They often eat so much until it feels like overdose. Another example: 

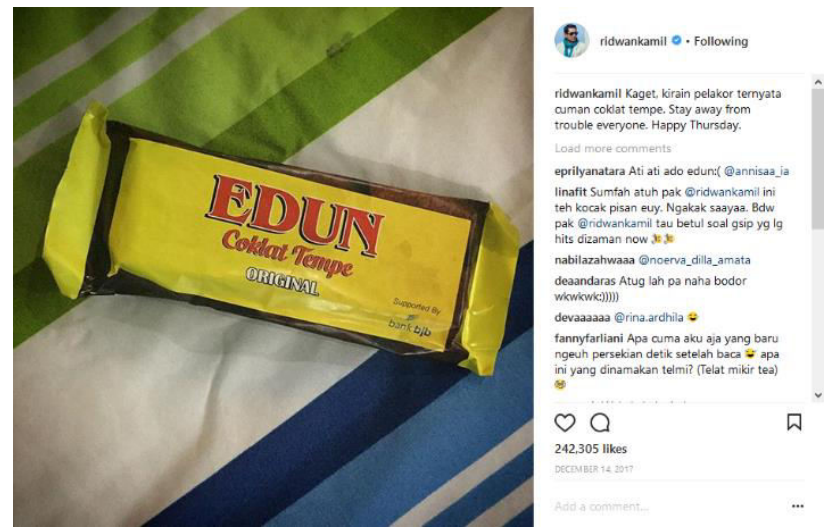

Picture 7

The paronymy pun on Picture 7 is somewhat contextual in Indonesian show business or entertainment. Edun is a pun of Jedun (Jennifer Dunn) who is famous as a notorious public figure in Indonesia, especially after having an affair with a married man. It is also explained in the caption with the word pelakor (perebut laki orang) that is a woman who caused trouble in someone's marriage life.

\section{Compound Pun}

This is kind of pun which contains two or more puns in the same sentence. Some examples of compound pun in Ridwan Kamil's Instagram account are as follows:

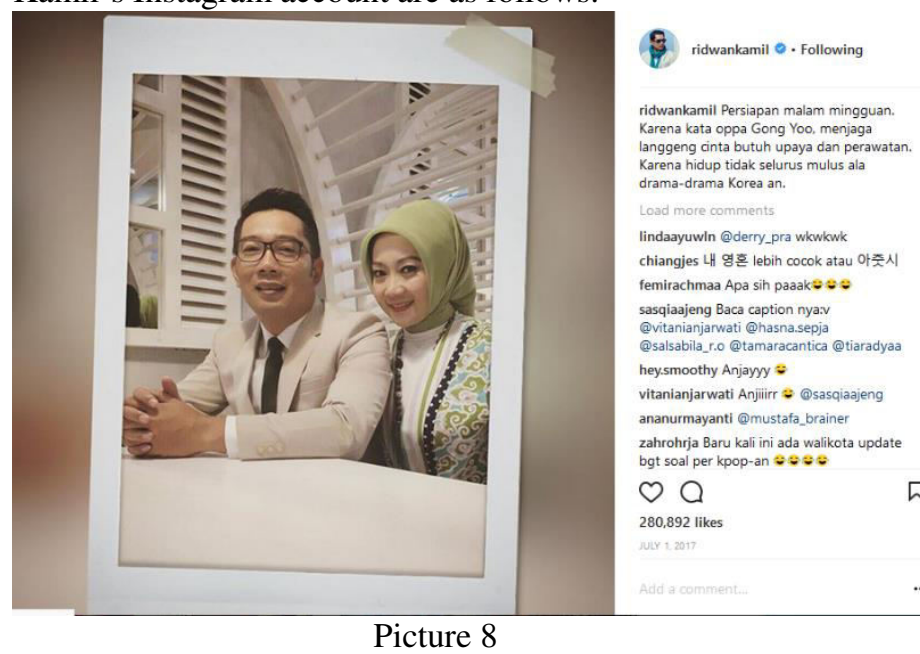

The pun on Picture 8 Karena kata oppa Gong Yoo, menjaga langgeng cinta butuh upaya dan perawatan. Karena hidup tidak selurus mulus ala drama-drama Korea an contains two puns in the same sentence. In many of his posts, Ridwan Kamil is often being up-to-date about Korean entertainment world.

\section{Recursive Pun}

This is kind of pun in which the second characteristic of the pun relies on the understanding of the first. Some examples of recursive pun in Ridwan Kamil's Instagram account are as follows:

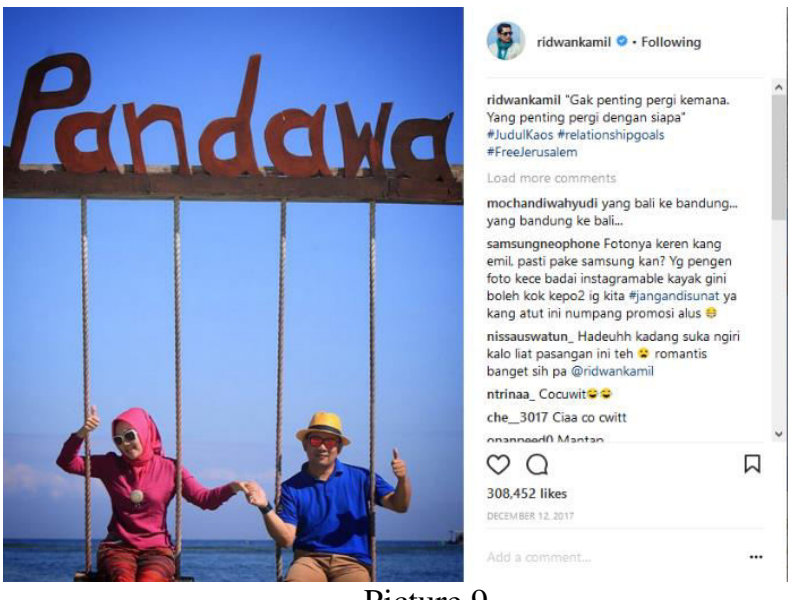

Picture 9

The pun on Picture 9 in caption gak penting pergi kemana, yang penting pergi dengan siapa is a recursive pun. Here, Ridwan Kamil means that the presence of the special one is more important than the destination. The context is revealed from the picture of Kang Emil and his wife. Another example:

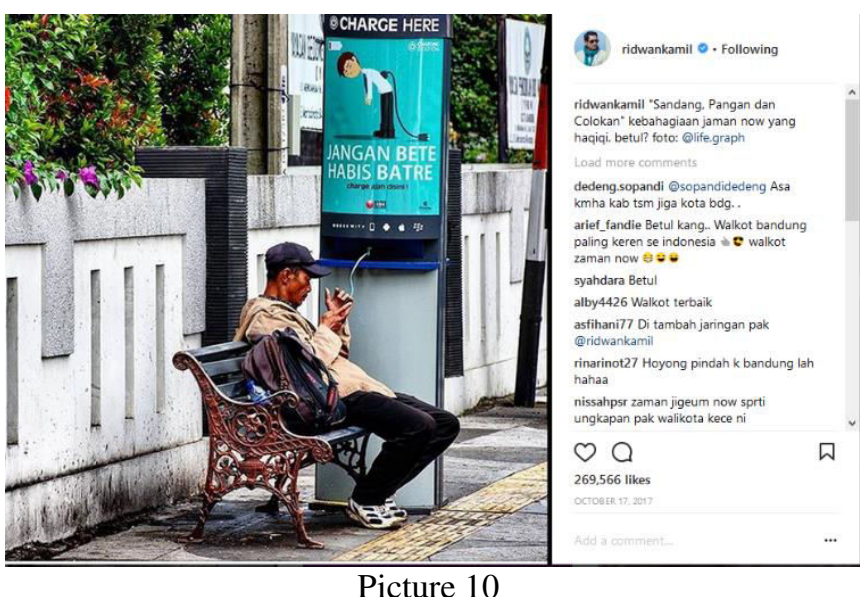

The pun in Picture 10 "sandang, pangan, dan colokan"kebahagiaan jaman now yang haqiqi is a recursive pun. It criticized a phenomenon in this era where most people have high dependency on smartphone that they can't be separated from colokan (electric plugs) to recharge the phone when the battery is low.

\section{Visual Pun}

This is kind of pun in which one or more puns are replaced by a picture. In logos, graphical symbols, emblems and insignia, etc. Some examples of visual pun in Ridwan Kamil's Instagram account are as follows: 

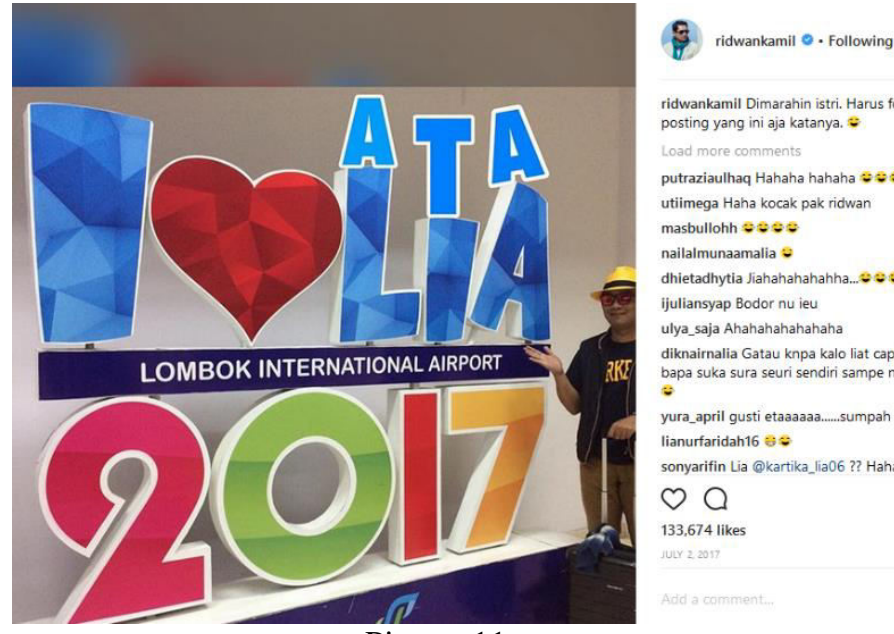

Picture 11

On Picture 11, the graphical symbol LIA stands for Lombok International Airport. I love LIA was edited by adding ATA to be I love ATALIA. Atalia is the name of Ridwan Kamil's wife.

\section{Function of Puns in Ridwan Kamil's Instagram Account 1. Creating Humor}

Puns are often used as a common source of humor in jokes. Ridwan Kamil often use puns as humor to provide amusement for his followers or anyone who reads his posts in Instagram. Some of his humorous posts often related to Korean drama such as:

Karena kata oppa Gong Yoo, menjaga langgeng cinta butuh upaya dan perawatan. Karena hidup tidak selurus mulus ala drama-drama Korea an.

The use of puns in his Instagram posts also typically entertaining to give a humorous meaning about entertainment world such as Korea or Hollywood movies.

\section{Providing Brevity}

As a mayor of Bandung, Ridwan Kamil often use Instagram to communicate and to socialize anything related to programs, policies, or activities in Bandung. One of the functions of puns in Ridwan Kamil's is to provide brevity in explaining government policy or program in an effective communication way.

"sandang, pangan, dan colokan"kebahagiaan jaman now yang haqiqi

The pun above is to inform the people about new facility of public electric plugs provided by the government of Bandung.

\section{Persuasion}

Social media is an effective way to inform anything, including to persuade people. Ridwan Kamil also used pun for sounding government policy or program in Bandung. geura seThor pajak bisi aya anu narok

The pun is to persuade people in Bandung to pay tax.

$$
\text { IV. CONCLUSION }
$$

There are six types of pun found in Ridwan Kamil's Instagram account, namely homonymic pun, homophonic pun, paronymy, compound pun, recursive pun, and visual pun. The puns have functions for creating humor, providing brevity, and persuasion.

\section{References}

Bader, Yousef. 2014. A Linguistic and Cultural Analysis of Pun Expressions in Journalistic Articles in Jordan. European Scientific Journal. 2: 18-29.

Chuandao, Yuan. 2005. English Pun and Its Classification. Language in India. 5 (4) (retrieved from http://www.languageinindia.com/april2005/englishpu n2.html) on 15 January 2018.

Creswell, John. 2012. Educational Research: Planning, Conducting, and Evaluating Quantitative and Qualitative Research (4th edition). Boston: Pearson Education.

2014. Research Design: Qualitative, Quantitative, and Mixed Methods Approaches (4th edition). California: Sage Publication.

Diaz-Perez, Fransisco Javier. 2012. The Use of Wordplay in Advertisements Published in Men's Magazines: A Comparative Study in the UK and Spain. Estudios Ingleses de la Universidad Complutense. 20: 11-36.

Giorgadze, Meri. 2014. Linguistic Features of Pun, Its Typology and Classification. European Scientific Journal. 2: 271-275.

Jojic, Olja. 2013. Lexical Puns in Sitcoms. Facta Universitatis Series: Linguistics and Literature. 11: 23-34.

Laviosa, Sara. 2005. Wordplay in Advertising: Form, Meaning and Function. Scripta Manent. 1 (1): 25-34.

Partington, Alan Scott. 2009. A Linguistic Account of Wordplay: the Lexical Grammar of Punning. Journal of Pragmatics. 41: 1794-1809.

Schwartz, Andrew, et.al. 2013. Personality, Gender, and Age in the Language of Social Media: the OpenVocabulary Approach. Plos One. 8 (9): 1-16.

Van Mulken, Margot, et.al. 2004. Puns, Relevance and Appreciation in Advertisements. Journal of Pragmatics. Article in Press: 1-15.

Vasquez, Camilla and Creel, Samantha. 2017. Conviviality through Creativity: Appealing to the Reblog in Tumblr Chat Posts. Discourse, Context \& Media. 20: 59-69. 